\title{
Human Skills by Heads of Secondary Schools towards Effective School Management in Makambako Town, Tanzania
}

\author{
Mwita S. Mwita \\ University of Iringa, Tanzania \\ Corresponding Mail: mwitasimion7@gmail.com
}

\begin{abstract}
This study sought to establish human skills by heads of the school toward effective school management at Makambako Town through qualitative approach. The population of the study comprised five heads of schools and 35 teachers through purposive sampling technique. Participants expressed a positive perception regarding human skills by school heads for effective school management. The human skills of the heads of school are vital in school management since such enables school heads to know how to work with others effectively, which arouses effective school management. Finally, human skills opened avenues for teamwork as subordinates were engaged in decision making and in executing specific managerial activities. It is recommended that the Tanzanian government should lay down a policy on managerial skills training for the newly appointed and continuing heads of schools as this will enhance effective school management, hence better attainment of school goals and objectives. The government should consider providing leadership training through workshops and seminars to managerial teams in schools. This will enhance effective school management in schools.
\end{abstract}

Keywords: Head of schools, human skills, teachers, school management, education.

\section{Introduction}

Provision of quality education is the ultimate goal of any education system. This goal, however, cannot be achieved without well-established and effective school management and administrative machinery (Ministry of Education Tanzania, 2014). The heads of schools are an important element for effective school management aspects like financial, human as well as physical, materials and infrastructural resources. Any successful school management needs heads of schools to use effective human skills in accomplishing managerial roles. Based on these assumptions, heads of schools are supposed to possess human skills as an essential aspect of school management. Possessing human skills in this sense connotes working and interacting with others in a good manner (Mintzberg, 2010).

According to Peterson and Van Fleet (2004), a skill is the ability to perform specific behavioral tasks or cognitive processes that are related to some particular profession. Human skill is the knowledge about and ability to work with people. It allows a leader to assist group members responsibilities in working cooperatively as a group to achieve common goals (Lei \& Skitmore, 2004).

Human skills give room for good human interaction in the school. The tasks ahead of any school administrator are so enormous that it requires many approaches to live up to expectations. The approaches apart from their personal qualities include having a good relationship with members of staff as well as delegating part of the responsibilities with authorities to the staff members (Francis \& Oluwatoyin, 2019).

One of the critical challenges facing Tanzania's public secondary school system is ineffective management in such aspects as human resource management as well as physical, materials and financial resources management (Kamete, 2014). This has results to the increase of indiscipline cases, misuse of school funds and poor relationships among the staff members in public secondary schools. The problem is even worse when the new head of school assumes the responsibility without specific training. This study investigated on effectiveness of human skills by heads in 
Makambako Town, Tanzania. The study guided by the following research questions:

1. How do the human skills of heads of schools encourage motivation towards effective school management?

2. How the human skills of heads of schools do enhanced teamwork towards effective school management?

3. What is the significance of communication strategies of the school heads for effective school management?

\section{Review of Related Literature}

This section presents the review of related literature and studies:

\section{Motivation}

Human skills are necessary for motivation of staff members at a working place. For the work to be done effectively in an institution, heads of institutions should motivate members through various ways. Motivation empowers people to achieve high levels of performance and overcome barriers (Pettinger, 2007). Therefore, motivation is an important characteristic of success (Hartnett, 2012) which helps members to reach their needs.

Papahiu (2010) revealed that once each level of need is met, however, one's motivation does not disappear; rather, an individual will be motivated to seek increased fulfilment by moving to the next level. For example, the more successful an individual is in the attempt to develop as a teacher, the harder that individual will strive to attain greater improvement. Day and Sammons (2016) explained that effectiveness of an organization depends on the human skills of the leaders. Therefore, school leaders need to cultivate human skills if their leadership is going to be successful.

Popescu, Iancu, Avram, Avram and Popescu (2020) argues that for effective school management to be realized, the head of school has the fundamental duty to mobilize and motivate people to achieve collective goals by clearly defining and communicating tasks, organizing the employees according to their tasks and providing them with the appropriate working environment. Brady and Tsay (2010) contend that motivational traits in an organized way influences people to behave in a desirable manner. According to Kamete (2014), human skills help the heads of schools to develop traits that motivate people as individuals or as a group to support the institution. Motivation develops teachers' attitude and satisfaction with their job, hence it incites teachers to work in optimal performance that contributes to effective performance.

\section{Teamwork}

Teamwork is another strategy through which heads of schools can demonstrate human skills. According to Makewa, Ngussa, Arego and Kuboja (2016), teamwork is a state of working together for the purpose of accomplishing set goals in organizations. Their study which looked at correlational Teamwork in Secondary Schools: A Case of Musoma Municipality, Tanzania further established a positive and strong relationship between teamwork and morale of work and a positive and strong relationship between teamwork and morale of work. Human skills create a base of teamwork which helps administrators to work with others and it enhances good relationship, solidarity, inclusive decision-making, harmony as well as accomplishment of required tasks. Teamwork involves cooperation, a behavior that leads towards collective achievement of the goal by individuals working in the organization (Laal \& Laal (2012). When the school goal is achieved collaboratively, no one will boast himself or herself, but all members will feel a sense of accomplishment. According to Austin and Seitanidi (2012) teamwork occurs when members reconstruct and reflect on the sequence of their actions and interactions that lead to the groups' outcomes, so members do clarify and improve their efforts to achieve the group's goals and maintain effective working relationships.

According to Bite (2012), human skills develop teamwork that helps to manage challenging issues in schools and as a result, increases the time taken on academic work, hence improving effective school management. Teamwork allows workers to engage in discussion, take responsibilities and thus become critical thinkers. Pitsoe and Isingoma (2014) argue that teamwork is an important component for effective and efficient leadership. It refers to a process where work is performed by a team to achieve a common goal. Within the context of the school environment, teamwork plays a key role in the effort to improve outcomes as it influences the level of motivation and capacity of teachers.

\section{Effective Communication}

Effective communication is essential for executing administrative plans as well as for handling day-today accomplishments through people. Slater (2020) 
argues that effective communication is all about conveying one's messages to other people clearly and unambiguously. It is also about receiving information that others are sending with as little distortion as possible. Therefore, the leader of the school needs to exercise communication skills that open ways to deliver information and at the same time receive information from subordinates. In organizational contexts, messages typically have a definite objective: to motivate, to inform, to teach, to persuade, to entertain, or to inspire. Effective communication in organizations centers on welldefined objectives that support the organization's goals and mission.

Heads of school need to better understand the target of an organization how the subordinates listen, how they learn and how they respond (Lazenby, 2005). This may help them to provide effective communication, which helps to pursue school activities. While there are various ways of classifying communication types, the most common ones are verbal and nonverbal communication which both the leaders and the subordinates use in day-to-day life knowingly or unknowingly. The two types are explained further below:

Verbal communication, according to Gulam, (2018), refers to the form of communication in which a message is transmitted verbally; communication is done by word of mouth or in writing.. Verbal communication in school management setting is done through staff meetings, parents' meeting, face-to-face meetings with individuals as well as student meetings. Narayana (2019) argue that verbal communication is easy and quick.

Nonverbal communication is all sorts of communication that is not spoken or written (Henry, 2021). Nonverbal communication has a great impact and influence on the receiver's decoding or interpretation. According to Sanina (2017), most of the communication is done by using body movements or facial epressions. Using the right gestures while speaking makes the message more effective.

\section{Research Methodology}

This section presents the methodology used in this study. It includes research design, population and sampling, data collection instruments and ethical considerations. This study employed a qualitative approach. The qualitative approach helped the researcher to collect and analyze participants' views and feelings under their natural settings. Qualitative studies are in-depth and in nature because they take a deep exploration of respondents to obtain information and help the researcher to study things in a natural setting.

\section{Research Design}

According to Kothari (2004), research design is the logical sequence in which the study is carried out, and it constitutes the blueprint for the collection, measuring and analysis of data. This study employed a case study design. Case study is a form of qualitative analysis where careful and complete observation of an individual, a situation or an institution is done.

\section{Population and Sampling}

Kombo and Tromp (2006) define a population as a group of individuals, objectives or items from which samples are taken for measurement. Purposive sampling was used to select five heads of schools and 35 teachers from five out of 16 public secondary schools in Makambako Town. Heads of schools were selected because they are responsible for school management roles and teachers were selected because they benefit directly with human skills of the heads of schools.

\section{Data Collection Instrument}

Interview and focus group discussions were used for data collection. The interview was face to face and was recorded by using a smartphone and notebook. In a focus group discussion, the researcher developed specific topics to be discussed; 4-6 participants were selected.

\section{Statistical Treatment of Data}

Data analysis is a process that involves coding, editing, classification and tabulation of data (Kothari, 2004). In this study, the data were analysed thematically. Thematic analysis is a method for analyzing qualitative data that entails searching across a data set to identify, analyze, and report repeated patterns (Kiger \& Varpio, 2020). Summary and direct quotations from participants were recorded. Thematic analysis fitted this study because it is used to analyze, classify and present themes (patterns) that relate to the questions under the following steps:

Familiarization: This phase involved reading and rereading the data to become deep and familiar with its content.

Coding: This phase involves generating and summarizing the main themes of the data that 
might be relevant to answering the research questions.

Generating initial themes: This phase dealt with examining the codes and organizing data to identify significant broader pattern of meanings.

Reviewing: This phase involved checking the candidate's themes against the questions to ensure that they tell a convincing stories and one that answers the research questions.

Defining and naming themes: This phase involved developing a detailed analysis of each theme, working out the scope and focus of each theme and determining the stories.

Reporting: This is the final phase which involved weaving together the analytic narrative and data extracts. It contextualized the analysis based on existing literature.

\section{Ethical considerations}

The researcher respected the rights of participants and the information provided guaranteed confidentiality. In addition, the researcher made full awareness of the purpose of this study to the participants and ensured that their names and identity are reserved.

\section{Results and Discussion}

This section presented findings and discussed it in the light of literature. It was guided by specific research questions.

Research Question 1: How do the human skills of heads of schools encourage motivation towards effective school management?

The research question sought to establish how the human skills of school heads encouraged motivation to subordinates. The results revealed that human skills helped the school heads to motivate the subordinates through encouraging the right teachers' attitudes.

Participants revealed that heads of schools motivated teachers and non-teaching staff members as a way of arousing commitment to work. The heads of schools motivated teachers who performed well in academic matters and the ones who supervised well different activities through appreciation letters. They also provided certificates of appreciation, gave some amount of money and granted opportunities for engaging in activities like marking districts, regional and national examinations. One of the teachers during the interview noted this by saying that,

The head of school motivates teachers who perform well in academic matters and supervision of different activities through writing a letter for congratulation, providing certificate of appreciation, giving some amount of money and granting different opportunities like marking districts, regional and national examinations. In addition, he motivated staff members in different ways like granting them a tea and lunch which encouraged commitment for teachers since teachers accomplished their tasks accordingly, hence enhancing effectiveness in the school management.

Furthermore, results from the Focus Group Discussion revealed that heads of schools motivated teachers through preparing ceremonies soon after opening the schools as a way of welcoming them for duties and arousing morale to work. One of the teachers revealed this by saying: "the head of school motivates teachers by preparing ceremonies soon after opening the schools as a way of welcoming them for school activities. Motivating teachers by preparing ceremonies opens teachers morally to work in optimal performance."

Results indicate that motivating staff members creates patriotism in the working environment, arousing teachers' spirits and commitment to work effective. Therefore, human skills are very important in management since they motivate teachers to perform their activities properly for achieving targeted goals in the school context. Similarly, Kamete (2014) agrees that motivation develops teachers' attitude and satisfaction with their job, hence it incites teachers to work in optimal performance that contributes to effective performance in schools activities.

Research Question 2: How do the human skills of heads of schools enhanced teamwork towards effective school management?

The question sought to establish how human skills enhanced teamwork in the schools under investigation.

The findings from the interviews and focus group discussions show that the heads of schools inspired teamwork in their respective schools to ensure effective school management. For example, during 
the interviews with teachers, it was revealed that heads of schools build a common base of the agreement through School Management Team (SMT) and staff meetings before moving forward to accomplish the task alone.

Furthermore, participants from the Focus Group Discussions revealed that the heads of schools engaged heads of departments to assist in managerial activities like discipline issues and in planning education matters which improve the academic performance, hence engaging teamwork that enhanced effective school management. One of the teachers said,

Formation of different departments in schools helps the workers to work as teamwork. This helps the heads of schools to reduce the workload; hence, they concentrate on specific school activities." This made the school activities to be easier, simple and efficiently done. Moreover, teamwork helped to diminish misunderstanding in schools. It further propelled cooperation and good relationships among the school workers. This accelerated effectiveness in school management because workers pursued different activities on time and made proper decisions in the process of school management.

This implies that building a base of agreement, in a team is important for effective school management since it influences cooperation and discourages misunderstanding and conflicts in schools as organizations. Teamwork also helps to make acute and proper decision in different managerial issues such as problem solving, resolving discipline cases and enriching good relationships among the teachers. Moreover, teamwork helped to accomplish tasks on time as well as reducing workload to the heads of schools. This study agrees with the study of Bite (2012), who argues that teamwork helps to manage challenging issues in schools and as a result, increases the time taken on academic work, hence improving effective school management. Teamwork allows workers to engage in discussion, take responsibilities and thus become critical thinkers. Also Pitsoe and Isingoma (2014) argue that teamwork is an important component for effective and efficient leadership. It refers to a process where work is performed by a team to achieve a common goal. Within the context of the school environment, teamwork plays a key role in the effort to improve outcomes as it influences the level of motivation and capacity of teachers.

Research Question 3: What is the significance of communication strategies of the school heads for effective school management?

This question sought to establish the significance of communication strategies by heads of schools for effective school management.

The results from the interview revealed that heads of schools provided information needed to accomplish tasks by using the leadership hierarchy and staff meetings. Furthermore, the heads of schools provided information, directly and indirectly through leadership hierarchy whereby immediate subordinates were fully engaged in administering specific school activities. Respondents further revealed that "provision of information to the subordinates made them aware of what should be done, how should it be done when should it be done and who should supervise." This suggests that provision of appropriate information maintained effective communication since workers become aware of the school procedure which helped them to accomplish instructions given by the heads of schools.

Results from the interview and focus group discussion further revealed that some school heads faced challenges in school management due to lack of sufficient human skills. This situation is due to lack of system of training heads of schools before appointing them to act in a managerial roles, hence, a deficiency to be addressed.

\section{Conclusions and Recommendations}

This section presents the conclusion and the recommendation of the study.

\section{Conclusions}

Participants expressed a positive perception regarding human skills by school heads for effective school management. The human skills of the heads of school are vital in school management since such enables school heads to know how to work with others effectively, which arouses effective school management. Also human skills opened avenues for teamwork as subordinates were engaged in decision making and in executing specific managerial activities. Finally, human skills reshape school heads to develop the understanding and provision of appropriate information; hence this maintained effective communication since workers become 
aware of the school procedure which helped them to accomplish the goals.

\section{Recommendations}

It is recommended that the Tanzanian government should lay down a policy on managerial skills training for the newly appointed and continuing heads of schools as this will enhance effective school management, hence better attainment of school goals and objectives. For that matter, the government should consider providing leadership training through workshops and seminars to managerial teams in schools. This will enhance effective school management in schools.

\section{References}

Austin, J. E., and Seitanidi, M. M. (2012). Collaborative Value Creation: A Review of Partnering Between Nonprofits and Businesses: Part I. Value Creation Spectrum and Collaboration Stages. Nonprofit and Voluntary Sector Quarterly, 41(5), 726-758. https://doi.org/10.1177/089976401245077 7.

Bite, V. (2012). Role of a Teacher in 21 st Century. An International Journal in English, 3, (3), ISSN 0976-8165.

Day, C., and Sammons, P. (2016). Successful School Leadership. United Kingdom: Education Development Trust. 978-1-909437-76-0.

Francis, O. B., \& Oluwatoyin, F. C. (2019). Principals'Personnel Characteristic Skills: a Predictor of Teachers' Classroom Management in Ekiti State Secondary Schools. International. Journal of Educational Leadership and Management, 7(1), 72. https://doi.org/10.17583/ij elm.2 019.3573

Gulam, K. (2018). 2 Types of communication. In communication Skills. Presented paper; university of Nairobi, Kenya: (p. 49).

Hartnett, M. (2012). Relationships between online motivation, participation, and achievement: More complex than you might think. Journal of Open, Flexible and Distance Learning, 16(1), [pp. 28-41].

Henry, L. (2021). Communication Skills. Kenya: Siaya Institute of Technology.

Kamete, J. M. (2014). The Influence of Headmaster's Managerial Skills on Effective School
Management: A Case of Public Secondary Schools in Mbeya -Tanzania. Proceedings of the Eighth Biennial Conference of the International Academy of Commercial and Consumer Law, 1(hal 140), 43. http ://www.springer.com/series/15440\%0Apap ers://ae99785b-2213-416daa7e3a12880cc 9b 9/ Pape r/p18311

Kombo, K. D. \& Trompo, A. L. D. (2006). Proposal and Thesis Writing; an Introduction. Nairobi: Pauline's Publications Africa.

Kothari, C. R. (2004). Research Methodology and Technology. New Delhi: Age International (P) Limited Pushers.

Laal, M., \& Laal, M. (2012). Collaborative learning: What is it? Procedia - Social and Behavioral Sciences, 31(June), 491-495. https://doi.org /10.1 016/j.sbspro.2011.12.092.

Lazenby, W. L. (2005). Informal and Formal channels of Communication preferred and used in the adoption of ranching practices by Livestock producers in the state of Nuevo León of North-eastern Mexico. A dissertation submitted to the Office of Graduate Studies of Texas A\&M University in partial fulfilment of the requirements for the degree of Doctor of Philosophy.

Lei, W., \& Skitmore, M. (2004). Project Management Competencies: A Survey of Perspectives from Project Managers in South East Queensland. Journal of Building and Construction Management, 9 (1), 1-12.

Makewa, L. N., Ngussa, B. M., Arego, S. W., and Kuboja, J. M. (2016). Correlational Teamwork in Secondary Schools: A Case of Musoma Municipality, Tanzania. Saudi Journal of Humanities and Social Sciences, $1(1), 26-31$.

Ministry of Education Tanzania. (2014.). EducationTraining Policy 1995.Tanian: instituty of Education.

Papahiu, P. C. (2010). Psicología educative. Journal of Perfiles Educativos, 32,(130). DOI: https://doi.org/10.22201/iisue.244861 67e.2010.130.

Peterson, T. O., \& Van Fleet, D. D. (2004). The ongoing legacy of R.L. Katz: An updated typology of management skills. Management Decision, 42(10), 1297-1308. 
https://doi.org/10.1108/002517404105689 80.

Pettinger, R. (2007). Management and motivation. Introduction to Management, 552-576. https://doi.org/10.1007/978-1-137-218995_25.

Pitsoe, V. J., and Isingoma, P. (2014). How do school management teams experience teamwork: A case study in the schools in the Kamwenge District, Uganda. Mediterranean. Journal of Social Sciences, 5 (3), 138-145. https://doi.org/10.5901/ mjss. 2014.v5n3p138.
Popescu, L., lancu, A., Avram, M., Avram, D., \& Popescu, V. (2020). The role of managerial skills in the sustainable development of SMEs in Mehedinti County, Romania.

Sustainability (Switzerland), 12 (3), 1-16. https://doi.org/10.3390/su12031119.

Sanina, A. (2017). The effectiveness of communication channels in government and business communication. In Information Polity, February 2018. https://doi.org/10 $.3233 /$ IP-170415.

Slater, L. (2006). Collaboration: A Framework for School Improvement Collaboration. Calgary: University of Calgary press. 